\title{
BENCANA DI BATAVIA DAN PEMINDAHAN PUSAT PEMERINTAHAN PADA MASA KOLONIAL BELANDA
}

\author{
Disaster in Batavia and the Relocation of Government Center \\ During The Dutch Colonial Period
}

\author{
Iwan Hermawan \\ Balai Arkeologi Jawa Barat \\ Jalan Raya Cinunuk KM. 17 Cileunyi Kabupaten Bandung 40623 \\ E-mail: iwan.hermawan@kemdikbud.go.id
}

\begin{abstract}
As the Center of Government during the Dutch colonial period, Batavia was not free from the threat of disasters, both natural disasters in the form of floods and non-natural disasters such as war and plague. This condition has prompted the discourse of moving the Central Government to an area that is considered safer and healthier. This paper intends to describe the threat of disaster as one of the factors driving the transfer of the center of government during the Dutch colonial era. Writing using descriptive analytic methods. When Daendels came to Java and served as Governor-General of the Dutch East Indies, one of his duties was to move the center of government from Batavia to a safer and healthier area. Daendels chose Weltevreden as the place to build the center of his government. At the end of the 19th century, the unhealthy condition of Batavia became the reason for moving the center of government to a healthier area but not far from the center of government at that time, Bandung was chosen to be the center of government to replace Batavia because it was healthier and safer. This condition shows that disaster is one of the factors driving the transfer of the center of government.
\end{abstract}

Keywords: government Center, Bandung, plague, flood, war

\begin{abstract}
Abstrak
Sebagai Pusat Pemerintahan pada masa kolonial Belanda, Batavia tidak terbebas dari ancaman bencana, baik bencana alam berupa banjir maupun bencana non alam seperti perang dan wabah. Kondisi ini mendorong digulirkannya wacana pemindahan pusat pemerintahan ke daerah yang dianggap lebih aman dan sehat. Tulisan ini bermaksud menguraikan ancaman bencana sebagai salah satu faktor pendorong pemindahan pusat pemerintahan pada masa Kolonial Belanda. Penulisan menggunakan metode deskriptif analisis. Ketika Daendels datang ke datang ke Pulau Jawa dan menjabat sebagai Gubernur Jenderal Hindia Belanda, salah satu tugasnya adalah memindahkan pusat pemerintahan dari Batavia ke daerah yang lebih aman dan sehat. Daendels memilih Weltevreden sebagai tempat untuk membangun pusat pemerintahannya. Pada akhir abad ke-19 kondisi Batavia yang tidak sehat menjadi alasan untuk pemindahan pusat pemerintahan ke daerah yang lebih sehat namun tidak jauh dari pusat pemerintahan saat itu, Bandung dipilih menjadi pusat pemerintahan pengganti Batavia dengan alasan lebih sehat dan aman. Kondisi ini menunjukkan bahwa bencana menjadi salah satu faktor pendorong pemindahan pusat pemerintahan.
\end{abstract}

Kata Kunci: pusat pemerintahan, Bandung, wabah, banjir, perang 


\section{PENDAHULUAN}

Batavia dibangun VOC di atas reruntuhan Kota Jayakarta setelah VOC merebutnya dari Pangeran Jayawikarta, selaku penguasa Pelabuhan Jayakarta wakil Kesultanan Banten, pada 30 Mei 1619 (Soemalyo, Ridwan, Atmoko, Ellisa, \& Hadi, 2007). Gubernur Jenderal VOC, Jan Pieterszoen Coen, menjadikan Batavia sebagai pusat perdagangan di Nusantara. Upaya tersebut dilakukan dengan meningkatkan aktivitas perdagangan di Pelabuhan Sundakalapa. Guna mendukung upaya tersebut, VOC memanfaatkan pulau-pulau di Kepulauan Seribu sebagai basis administrasi dan pertahanan, dan membuka pintu lebar bagi pedagang dan pendatang etnis Tionghoa (Noviyanti, 2017). Pembangunan kota Batavia diperintahkan oleh Jan Pieterzoen Coen didasarkan peta buatan Simon Stevin, seorang perencana kota di Belanda. Hal ini sesuai permintaan Heeren XVII (Dewan Direksi VOC) yang meminta Stevin merancang sebuah benteng dengan balai kota dan menjamin pemandangan menawan di pusat kota. Rencana kota berbentuk segi empat bersisi lurus sesuai dengan rencana kota-kota di Belanda berdasarkan rumusan benteng Romawi. Kota dikelilingi parit-parit dan tembok-tembok kota yang diperkuat dengan benteng-benteng yang mengelilingi kota. Antara 1619 - 1627, benteng Jacatra semakin luas dan mencapai tiga kali lipat dari luas semula. Orang Belanda berupaya menciptakan kota Belanda dengan rumah-rumah khas Belanda di Batavia dengan kondisi iklim tropis yang panas dan berawarawa, kondisi lingkungan yang berbeda jauh dengan kondisi di Negeri Belanda (Gunawan, 2010, hal. 35-39). Seperti halnya kota-kota di Belanda, Batavia dilengkapi dengan kanalkanal yang saling berpotongan dan tersambung dengan terusan lurus (Kalibesar) yang merupakan sodetan $\mathrm{Ci}$ Liwung yang memotong Batavia menjadi dua. $\mathrm{Ci}$ Liwung, merupakan jalur lalu lintas utama ke pedalaman. Kanal-kanal tersebut merupakan prasarana transportasi yang menghubungkan antar bangunan di dalam kota dan juga sebagai prasarana transportasi penghubung Batavia dengan wilayah pedalaman di Selatannya.

Keberadaan kanal juga dimanfaatkan sebagai tempat mandi, cuci, dan kakus (MCK) warga Batavia dan sekaligus sebagai tempat pembuangan limbah rumah tangga. Kondisi ini berpengaruh pada kebersihan lingkungan Batavia, karena kanal dipenuhi oleh limbah rumah tangga dan kotoran manusia. Guna menjaga kebersihan lingkungan, dibuat aturan yang melarang warga untuk membuang hajat di kanal-kanal dan Ci Liwung pada siang hari. Warga hanya diperkenankan melakukan aktifitas tersebut (membuang hajat) pada malam hari hingga menjelang pagi. Berdasarkan aturan tersebut, maka orang beramai-ramai membuang kotoran (limbah kakus) ke kanal pada tengah malam sampai menjelang pagi (Shahab, 2010, hal. 29-30).

Pada tahun 1699 terjadi aktivitas vulkanik di selatan Batavia, yaitu di Gunung Salak

yang menimbulkan longsoran. Dampak dari aktivitas tersebut, adalah meningkatnya sedimentasi sungai-sungai yang berhulu di Gunung Salak dan bermuara di Laut Jawa. Setelah letusan Gunung Salak tahun 1699, garis pantai bergeser $75 \mathrm{~m}$ ke arah laut setiap tahun (Gunawan, 2010, hal. 9). Hal ini menunjukan tingginya sedimentasi di muara Ci Liwung yang berdampak pada pada pendangkalan sungai dan kanal di Batavia. Akibat pendangkalan tersebut, aliran air di kanal dan Ci Liwung menjadi terhambat tergenang 
membentuk rawa-rawa. Kondisi ini diperburuk dengan kebiasaan warga yang menjadikan sungai dan kanal sebagai tempat pembuangan limbah rumah tangga dan kotoran manusia.

Rawa-rawa yang terbentuk di sekitaran Batavia serta buruknya sanitasi lingkungan menjadikannya sarang berbagai macam penyakit berbahaya, yaitu malaria, kolera, dan pes. Jumlah penduduk Batavia yang menderita dan meninggal akibat penyakit berbahaya tersebut terus meningkat dari waktu ke waktu, hingga Batavia memperoleh julukan Het Graf der Hollanders (Kuburan Orang Belanda) (Soemalyo et al., 2007). Selain itu, posisi Batavia yang berada di tepi pantai menjadikannya sasaran yang mudah untuk diserang musuh dari arah Laut Jawa yang pada awal abad ke-19 sudah diblokade Angkatan Laut Inggris. Kondisi tersebut tidak menguntungkan bagi pemerintahan Belanda. Hal inilah yang mendorong terjadinya perubahan arah pembangunan ke daerah-daerah pinggiran yang lebih sehat (Ellisa, 2018), termasuk memindahkan pusat pemerintahan dari Oud Batavia ke Weltevreden (Niew Batavia) yang dilakukan pada masa Gubernur Jenderal HW. Daendels.

Pada perkembangan berikutnya, yaitu di penghujung abad ke-19 dan awal abad ke20, lokasi pusat pemerintahan di Neuw Batavia yang wilayahnya berada di dataran rendah pesisir utara Jawa tetap dihantui oleh permasalahan lingkungan yang kurang mendukung bagi pusat pemerintahan. Banjir akibat luapan $\mathrm{Ci}$ Liwung dan anak-anak sungainya, serta penyakit khas daerah tropis, seperti malaria, kolera, dan pes menghantui warga Neuw Batavia. Selain itu, secara pertahanan Batavia kurang terlindungi. Daerahnya yang berada di tepi pantai merupakan sasaran empuk bagi musuh yang datang dari arah Laut Jawa.

Berkenaan dnegan kondisi lingkungan geografis Batavia sebagai pusat pemerintahan, hasil penelitian HF Tillema tahun 1916 menunjukan bahwa kota-kota pelabuhan di Pulau Jawa tidak sehat, termasuk Batavia kurang memenuhi syarat sebagai pusat pemerintahan dan menyarankan untuk memindahkan pusat pemerintahan dari Batavia ke daerah pegunungan yang memiliki cuaca yang sejuk (Kunto, 1984, 1986).

Berdasarkan uraian tersebut, permasalahan yang diajukan pada tulisan ini, adalah Apa dan bagaimana keterkaitan antara bencana dengan pemindahan pusat pemerintahan pada masa Kolonial Belanda. Guna menjawab permasalahan tersebut, dipergunakan metode deskriptif analisis Pendekatan keruangan digunakan guna melihat faktor -faktor pendorong ditinggalkannya Pusat pmerintahan lama dan ditentukannya Pusat Pemerintahan baru. Pengumpulan data dilakukan melalui kegiatan studi pustaka.

\section{PEMBAHASAN}

\section{Weltevreden sebagai Pengganti Batavia}

Weltevreden merupakan kawasan yang saat ini dikenal dengan nama Lapang Banteng. Hal ini dikarenakan pusat dari kawasan ini, adalah lapangan yang sebelumnya bernama Waterlooplein. Secara administratif berada di Jakarta Pusat, pada koordinal antara $6,1678^{\circ} \mathrm{LS}-6,1816^{\circ} \mathrm{LS}$ dan $106,8295^{\circ} \mathrm{BT}-106,8420^{\circ} \mathrm{BT}$. Secara Geografis dibatasi oleh Jalan Kantor Pos dan Jalan Doktor Sutomo di bagian utara, Jalan Gunung Sahari dan Pasar Senen di bagian timur, Jalan Prapatan di bagian selatan, serta Sungai Ci Liwung di bagian 
barat. Pada awal abad ke-19, kawasan Weltevreden merupakan kawasan yang dipilih oleh Gubernur Jenderal H.W. Daendels sebagai pusat pemerintahan kolonial Belanda sebagai pengganti pusat pemerintahan lama di kawasan Benteng Batavia (Tim Penyusun, 2011).

Pemindahan pusat pemerintahan Hindia Belanda dari Benteng Batavia ke Weltevreden merupakan salah satu bentuk realisasi tugas utama yang diberikan Raja Lodewijk kepada Daendels sebagai Gubernur Jenderal Hindia Belanda. Tugas utama yang diemban oleh Daendels tersebut, adalah mempertahankan Pulau Jawa dari serangan pasukan Inggris selama mungkin, dan membenahi administrasi di wilayah koloni. Kondisi lingkungan Batavia yang semakin rusak dan tidak sehat mendorong Daendels melakukan perbaikan lingkungan Batavia. Perbaikan lingkungan tersebut dilakukan dengan cara memperbaiki saluran air, menimbun genangan air kotor, serta mengaktifkan Rumah Sakit. Selain itu, Daendels menata jalan, kanal, sungai, dan pantai yang sebelumnya kurang ditangani secara baik sehingga waktu tempuh perjalanan bisa menjadi lebih singkat (Marihandono, 2012).

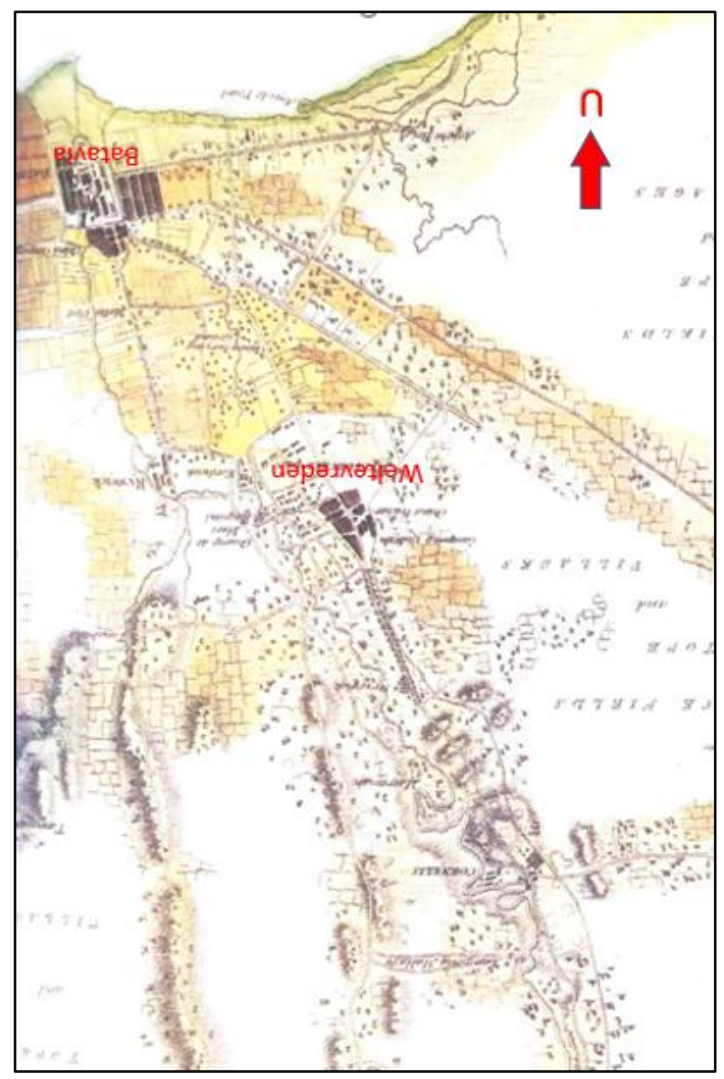

Gambar 1. Lokasi Weltevreden dan Batavia berdasarkan Peta Route of The British Army-1811 (Sumber: Thorn, 2011: Plate VI).

Akibat kerusakan lingkungan Batavia yang parah, Daendels memutuskan untuk memindahkan pusat pemerintahan ke daerah yang lebih aman dan sehat. Dengan alasan strategis, awalnya pusat pemerintahan akan dipindahkan ke Semarang atau Surabaya, 
karena dekat dengan pusat-pusat pertahanan Belanda. Pemindahan tersebut urung dilaksanakan karena besarnya biaya dan ancaman penyerangan Inggris. Daendels memindahkan pusat pemerintahan ke daerah yang lingkungannya lebih baik dan tidak jauh dari pusat pemerintahan lama, yaitu ke Weltevreden (Gunawan, 2010). Pembangunan Perkotaan mulai diorientasikan ke daratan, jalan-jalan dibangun hingga jauh ke pedalaman. Kondisi ini mendorong berkembangnya pusat-pusat permukiman baru di luar kota yang lebih sehat (Hermawan \& Abrianto, 2020).

Guna merealisasikan pemindahan pusat pemerintahan, tahun 1809 Daendels membangun Istana Gubernur Jenderal di sekitar Paradeplaats dengan gaya arsitektur Empire Style yang berbau Perancis. Gaya ini kemudian dikenal dengan Indische Empire Style, yaitu gaya arsitektur Empire Style yang disesuaikan dengan kondisi iklim, teknologi dan bahan bangunan setempat (Handinoto, 2010). Pembangunan istana tersebut dilakukan dengan menggunakan bahan bangunan yang berasal dari reruntuhan benteng di Oud Batavia. Istana tersebut tidak sempat diselesaikannya karena pembangunan yang berjalan lambat akibat suasana perang dan dirinya dipanggil pulang. Penggantinya, yaitu Janssens hanya menutupi bangunan yang belum beratap dengan atap rumbia. Bangunan tersebut baru benar-benar diselesaikan pada zaman pemerintahan Gubernur Jenderal Du Bus de Ghisignies pada tahun 1828 (Heuken, 1997; Merrilles, 2001). Guna mendukung pertahanan Batavia dibangun benteng pertahanan di Meester Cornelis yang lokasinya di Selatan Weltevreden (Heuken, 1997, hal. 204-205).

Sebagai pusat pemerintahan, Weltevreden dikelilingi oleh jalan yang saling memotong dan berhubungan dengan pusatnya adalah Paradeplaats (Lapangan Parade). Tata ruang Weltevreden diinspirasi dari penataan kota-kota tua di Nusantara, di mana satu pusat dikelilingi oleh jalan yang saling memotong. Di pusat kota inilah tempat para pegawai pemerintah kolonial. Penduduk bumiputera yang miskin tinggal di perkampungan sekitar kota, masuk dan pergi ke kota untuk bekerja. Menurut Werthein, Weltevreden menyerupai kota lama di Indonesia, yaitu bangunan luas dengan halaman luas menyerupai alun-alun. Arsitektur ini merupakan perubahan fundamental rumah tinggal di Hindia Belanda (Gunawan, 2010). Kondisi tersebut menunjukkan terdapat perbedaan penataan tata ruang antara Batavia dengan Weltevreden ketika mulai dibangun sebagai kawasan pusat pemerintahan. Pada tata ruang kota Weltevreden, urat nadi transportasi dalam kota dan ke luar kota adalah jalan raya, sehingga jalan banyak bersimpangan dan berhubungan dengan jalur utamanya adalah Jalan Raya Pos yang menghubungkan Batavia dengan Buitenzorg (Bogor). Jalan Raya Pos merupakan jalur trans Jawa yang menghubungkan pantai barat dan pantai timur Pulau Jawa. Jalan raya ini membentang dari Anyer sampai Panarukan.

Berdasarkan uraian tersebut diketahui alasan Daendels memilih memindahkan Pusat Pemerintahan ke Weltevreden, karena (1) jarak yang tidak terlalu jauh $( \pm 5 \mathrm{Km})$ dari pusat pemerintahan lama di Oud Batavia dan secara alami terlindung; (2) Kondisi lingkungan Weltevreden lebih sehat dibanding Oud Batavia; (3) Weltevreden terhubung dengan jaringan jalan raya pos yang menghubungkan kota-kota di Pulau Jawa dari Anyer sampai Panarukan, sehingga dapat memudahkan pengungsian ke wilayah pedalaman (Bogor dan 
Priangan) jika diserang musuh (Hermawan \& Abrianto, 2020). Keberadaan jalan raya pos sebagai jalur pengungsian terjadi pada saat penyerangan inggris ke Batavia. Gubernur Jenderal Janssens dan Mayor Le Blanc dengan pasukan bekuda pada pertempuran tanggal 26 Agustus 1811 mundur ke Buitenzorg setelah benteng pertahanan Cornelis jatuh ke tangan pasukan Inggris yang dipimpin oleh Jenderal Sir Samuel Auchmuty. Pada saat mundur, Jansens memerintahkan pasukannya membakar jembatan Ci Liwung di Kampung Melayu. Dari Buitenzorg, Jenderal Janssens bergerak menyusuri jalan raya pos sampai Semarang dan bertahan di Benteng Ungaran dan selanjutnya berpindah ke Benteng Salatiga sampai akhirnya menyerah serta menandatangani Kapitulasi Ungaran pada tanggal 18 September 1811 (Thorn, 2011, hal. 59-99).

\section{Pemindahan Ibukota ke Bandung $>>>>>>>>>>>>>>>>>>$}

Banjir merupakan bencana yang selalu mengancam Batavia, walau pemerintahan sudah berpindah dari Oud Batavia ke Nieuw Batavia (Weltevreden). Pada tanggal 1 Januari 1892, beberapa daerah di Weltevreden mengalami banjir. Banjir juga terjadi di pinggiran kota yang berada di daerah aliran Ci Liwung, termasuk Pasar Minggu. Banjir ini terjadi karena hujan lebat lebih dari 8 jam. Satu tahun kemudian, awal tahun 1893, terjadi Banjir yang tidak hanya merusak jalan-jalan di weltevreden tetapi juga merusak perekonomian. Kondisi tersebut semakin diperparah dengan berjangkitnya penyakit Kolera yang mengakibatkan banyak warga yang meninggal dunia. Bencana banjir berikutnya terjadi di tahun 1895, 1899, dan 1904. Pada tanggal 19 Februari 1909 terjadi Banjir yang diakibatkan oleh derasnya hujan sehingga kanal-kanal yang ada tidak mampu menampung aliran air. Akibat sebagian besar daerah di Batavia terendam air, De Locomotief mengkritik pemerintah dalam penanganan banjir dengan menulis berita "Batavia Onder Water" sebagai sindiran kepada lembaga BOW (Burgelijke den Openbare Werken), lembaga pemerintah yang menangani sarana prasarana pemerintah, termasuk pengairan. Banjir di Batavia terus berlanjut walau upaya penanggulangan dilakukan pemerintah yaitu dengan membangun Banjir Kanal (Gunawan, 2010, hal. 112-142).

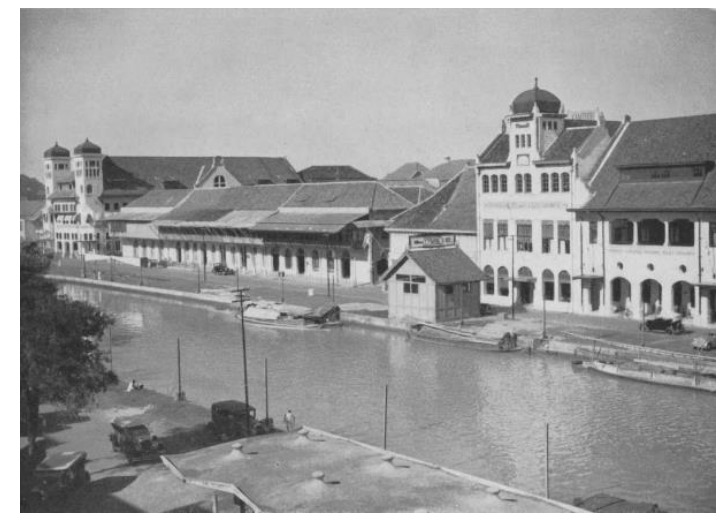

Gambar 2. Kali Besar, salah satu Kanal di Oud Batavia (Sumber: Gementee Batavia, 1937, hal. 45). 
Berkenaan dengan kesehatan lingkungan Batavia, Laporan H. F. Tillema tentang kota-kota pantai di Pulau Jawa, menyebutkan bahwa umumnya kota-kota pelabuhan di Jawa, termasuk Batavia, udaranya panas, tidak sehat, dan mudah terjangkit wabah. Hawa tidak nyaman mengakibatkan orang cepat lelah, semangat kerja menurun. Kondisi tersebut kurang memnuhi persyaratan sebagai "Pusat Pemerintahan". Pada laporan tersebut, Tillema mengusulkan kepada Gubernur jenderal J. P. Graaf van Limburg Stirum (1916-1921), agar Ibukota Pemerintahan Hindia Belanda dipindahkan ke Bandung yang udaranya sejuk. Usulan tersebut mendapat dukungan Profesor J. Klopper, Rektor Bandoengsche Technische Hoogeschool (sekarang ITB) (Katam, 2009; Kunto, 1984).

Kekalahan Belanda atas Inggris yang terjadi di awal abad ke-19 menjadi pelajaran berharga dalam perencanaan pertahanan Hindia Belanda. Batavia sebagai pusat pemerintahan Hindia Belanda perlu dilindungi yaitu dengan menempatkan pasukan militer tidak jauh dari Batavia dan terlindung dari serangan musuh. Pilihan jatuh pada Cimahi yang lokasinya tidak jauh dari Batavia dan dilalui oleh Jalur kereta api Batavia - Bandung Cilacap. Pintu masuk dari pesisir utara atau selatan hanya dua, yaitu jalan raya pos dan jalur kereta api. Lokasinya yang berada di Cekungan Bandung dibentengi secara alam oleh pegunungan yang mengelilinginya (lihat gambar 2).

Pelaksanaan pembangunan pangkalan militer di Cimahi dipimpin oleh Genie Officier Kapitein Fisher yang dibantu oleh Luitenant V. L. Slors. Penempatan pasukan militer Hindia Belanda secara terkonsentrasi di Cimahi dilakukan secara bertahap. Pada tahun 1885 terdapat tiga batalyon pasukan militer yang bermarkas di Cimahi, yakni Infanteri, Genie (zeni), dan Artileri. Pasukan Artileri dibagi menjadi tiga, yaitu Artileri Gunung (Bergartelerie), Artileri Lapangan (Veldartelerie), dan Artileri Serangan Udara. Pada tahun 1896 Cimahi ditetapkan sebagai Garnisun Militer dan pada tahun 1908 kota Bandung ditetapkan sebagai Pusat Garnisun Hindia Belanda (BPCB Banten, 2014; Katam, 2009).

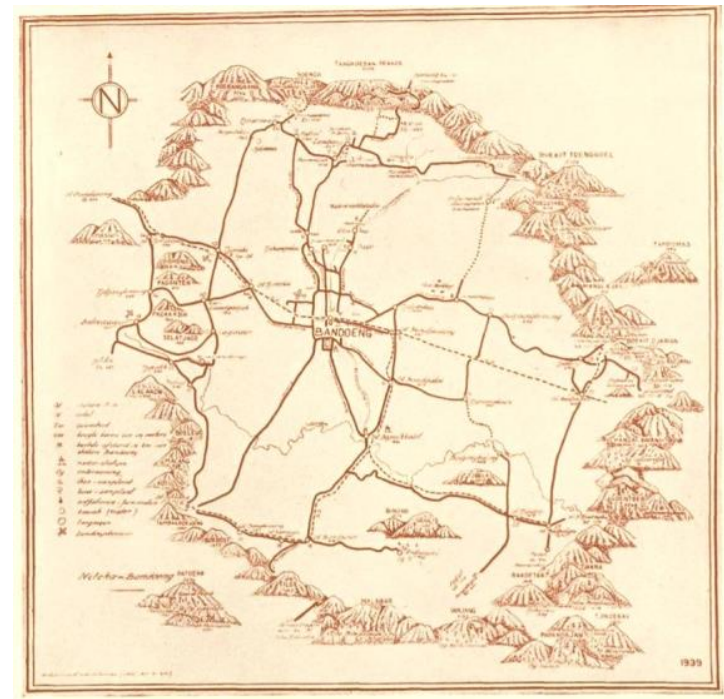

Gambar 3. Situasi Bandung yang dikelilingi Gunung (Kunto, 1984; 1986). 
Pemindahan ibu kota Hindia Belanda direalisasikan menjelang 1920. Pembangunan gedung-gedung perkantoran untuk bakal Pusat Pemerintahan baru dilakukan sebagai persiapan. Lahan seluas $27 \mathrm{Ha}$ dipersiapkan oleh Pemerintah Kotapraja Bandung untuk kawasan pusat pemerintahan Hindia Belanda (Gouvernements Bedrijven). Di lokasi tersebut akan dibangun 14 gedung pemerintahan. Berdasarkan denah rencana komplek Pusat pemerintahan Hindia Belanda, bentuknya mirip dengan Mahkota Kerajaan Belanda. Pembangunan Komplek Pusat pemerintahan Hindia di Bandung harus terhenti akibat Malaise tahun 1930-an .

Pemindahan instansi pemerintah diawali perpindahan kantor Jawatan Kereta Api Negara (Staatsspoorwagen), Pos dan Telpon, Departement van Geovernements Bedrijven (GB) yang membawahi Dinas Pekerjaan Umum. GB menempati Gedung Sate yang dibangun dengan biaya 6 juta Gulden dan dirancang oleh arsitek J. Gerber. Lalu diikuti oleh perpindahan sebagian Departemen Perdagangan dari Bogor, Kantor Keuangan, dan Lembaga Cacar yang bergabung dengan Institut Pasteur. Kementerian Pertahanan (Departement van Oorlog) sendiri secara bertahap sudah memindahkan personilnya sejak 1916. Instansi yang belum pindah ke Bandung, adalah Departemen voor Algemeen Bestuur (Departemen dalam negeri), departement van Ondrwijs en Eerediest (Departemen Pendidikan dan Pengajaran), dan Volsraad (Kunto, 1984, hal. 249-251).

Pemindahan terakhir adalah kantor Gubernur Jenderal, yang dipindahkan pada awal Maret 1942, ketika Belanda mulai ditekan oleh Jepang di Batavia (Hermawan, 2011). Gubernur Jenderal Hindia Belanda, Tjarda van Starkenburg Stakhouwen, memindahkan aktivitas Pemerintahannya ke Bandung dan menyerahkan Batavia kepada Jepang tanpa perlawanan dan memfokuskan pertahanan di Pegunungan Priangan. Pada saat yang bersamaan, Bandung sudah dijadikan sebagai tempat pengungsian orang-orang Belanda dari Batavia, Buitenzorg, dan bagian dataran lain sejak 2 Januari 1942 (Onghokham, 1987, hal. 345-352). Pengungsian Pejabat-pejabat dan penduduk sipil Belanda ke Australia juga dilakukan melalui Kota Bandung, yaitu dengan menggunakan pesawat melalui Lapangan Udara Andir dan dengan menggunakan kereta api ke Pelabuhan Cilacap untuk selanjutnya menggunakan kapal laut menuju Australia melalui Samudera Hindia. Pejabat Belanda yang berhasil terbang ke Australia dari Bandung, adalah Letnan Jenderal H.W. van Mook dan Perwira Intelejen Mayor S.H. Spoor pada tanggal 8 Maret 1942 dengan menggunakan Pesawat Dakota yang tinggal landas dari Jalan Buahbatu, karena landasan Lapangan Udara Andir sudah tidak dapat didarati karena dibombardir pasukan Jepang (Hermawan, 2011, hal. 158).

Uraian tersebut menunjukan bahwa pembangunan jalan raya pos Anyer - Panarukan pada masa pemerintahan Gubernur Jenderal Daendels dan pembangunan Jalur kereta api Batavia - Buitenzorg - Bandung - Cilacap dan Batavia - Karawang - Purwakarta Padalarang tidak hanya ditujukan sebagai jalur penghubung antar wilayah untuk kepentingan ekonomi, namun menjadi jalur pengungsian yang efektif ketika pusat pemerintahan di Batavia diserang musuh. Hal ini terlihat dari Kota Bandung dijadikan tempat pengungsian orang-orang Eropa dari Batavia dan Buitenzorg pada saat Jepang masuk menyerbu Batavia. 


\section{SIMPULAN}

Pemindahan pusat pemerintahan dilakukan guna menghindari bencana yang selalu terjadi atau diperkirakan akan terjadi, kesehatan lingkungan dan lokasi yang terlindung merupakan alasan untuk memindahkan pusat pemerintahan. Pandemi di Oud Batavia sebagai akibat dari turunnya kualitas lingkungan kota dan ancaman angkatan laut Inggris mendorong Daendels untuk memindahkan pusat pemerintahan ke pedalaman yang lebih sehat dan terlindung serta terhubung dengan jalur pelarian/pengungsian.

Rencana pemindahan pusat pemerintahan ke Bandung juga tidak terlepas dari ancaman bencana alam serta ancaman keamanan. Pemilihan Bandung sebagai pusat pemerintahan menggantikan Batavia karena Bandung merupakan tempat strategis. Bandung terlindung secara alami, terhubung oleh jalan raya pos dan jalur kereta api yang menghubungkan pantai utara dan selatan Pulau Jawa merupakan tempat yang tepat untuk lokasi pusat pemerintahan pengganti Batavia. Kedua jalur transportasi tersebut dan jalur udara langsung dari Bandung ke luar negeri merupakan jalur pengungsian jika pusat pemerintahan jatuh ke tangan musuh.

\section{DAFTAR PUSTAKA}

BPCB Banten. (2014). Cimahi, Kota Garnisun. Diunduh 17 Agustus 2021 (https://kebudayaan.kemdikbud.go.id/bpcbbanten/cimahi-kota-garnisun/)

Ellisa, E. (2018). The Recreational Landscape of Weltevreden Since Indonesian Colonization. Journal of Urban Culture Research, 17, 12-30. (https://doi.org/10.14456/JUCR.2018.8)

Gunawan, R. (2010). Gagalnya Sistem Kanal: Pengendalian Banjir Jakarta dari Masa ke Masa. Jakarta: Kompas.

Handinoto. (2010). "Indische Empire Style" Gaya Arsitektur "Tempo Doeloe" yang

Sekarang sudah mulai Punah. In Arsitektur dan kota-kota di Jawa pada masa Kolonial (hal. 43-58). Yogyakarta: Graha Ilmu.

Hermawan, I. (2011). Bandung Sebagai Ibukota Hindia Belanda. Dalam A. Akbar (Ed.), Arkeologi Masa Kini (hal. 129-143). Jatinangor: Alqaprint.

Hermawan, I., \& Abrianto, O. (2020). Pola Tata Ruang Weltevreden dan Fungsi Ruang Kota. PANALUNGTIK, 3(1), 1-13. (https://doi.org/10.24164/pnk.v3i1.32)

Heuken, A. S. (1997). Tempat-tempat Bersejarah di Jakarta. Jakarta: Cipta Caraka Loka. Katam, S. (2009). Gedung Sate Bandung. Bandung: Kiblat Buku Utama.

Kunto, H. (1984). Wajah Bandoeng Tempo Doeloe. Bandung: Granesia.

Kunto, H. (1986). Semerbak Bunga di Bandung Raya. Bandung: Granesia.

Marihandono, D. (2012). Pembangunan Kota Berbasis Multikultur: Studi Kasus Pembangunan Weltevreden pada Awal Abad XIX. Prosiding Seminar Internasional Multikultural \& Globalisasi, 133-143. (https://multikulturalui.files.wordpress.com/2013/05/prosiding-simg-ui-2012-jilid-113.pdf)

Merrilles, S. (2001). Batavia, in Nineteenth Century Photographs. Singapore: Archipelago Press. 
Noviyanti, R. (2017). Gubernur Jenderal VOC Jan Pieterszoon Coen dan Pembangun Kota Batavia (1619-1629). Sosio e-kons, 9(1), 54. (https://doi.org/10.30998/sosioekons.v9i1.1688)

Onghokham. (1987). Runtuhnya Hindia Belanda. Jakaarta: Penerbit Gramedia.

Shahab, A. (2010). Batavia Kota Hantu. Jakarta: Penerbit Republika.

Soemalyo, Y., Ridwan, K., Atmoko, T. U., Ellisa, E., \& Hadi, A. (2007). Sejarah Kotatua. Jakarta: Dinas Kebudayaan dan Permuseuman Provinsi DKI Jakarta.

Thorn, W. (2011). Penaklukan Pulau Jawa: Pulau Jawa di Abad Sembilan belas dari Amatan Seorang Serdadu Kerajaan Inggris (Novriatri, Penerj.). Jakarta: Elex Media Komputindo.

Tim Penyusun. (2011). Laporan Penyelenggaraan Penelitian Arkeologi Pola Tata Ruang Pusat Pemerintahan Hindia Belanda di Batavia (Weltevreden) Abad ke-19 - Abad ke20 Provinsi DKI Jakarta. Bandung.

\section{HASIL DISKUSI}

Tidak Ada Pertanyaan 